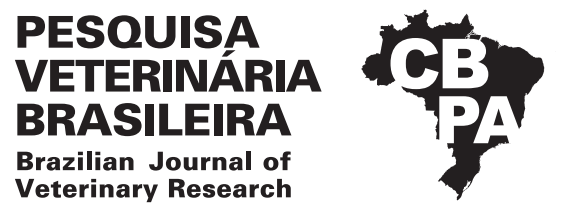

Pesq. Vet. Bras. 38(7):1259-1263, julho 2018 DOI: $10.1590 / 1678-5150-P V B-5480$

Original Article

Animais de Produção/Livestock Diseases

ISSN 0100-736X (Print)

ISSN 1678-5150 (Online)

\title{
Embryonic mortality and abortion in goats caused by ingestion of Poincianella pyramidalis ${ }^{1}$
}

\author{
José R.S. dos Santos², José R.G. Lopes², Marcia A. Medeiros², Édipo M. Campos², \\ Rosane M.T. Medeiros ${ }^{2}$ and Franklin Riet-Correa ${ }^{3 *}$
}

\begin{abstract}
Santos J.R.S., Lopes J.R.G., Medeiros M.A., Campos E.M., Medeiros R.M.T. \& Riet-Correa F. 2018. Embryonic mortality and abortion in goats caused by ingestion of Poincianella pyramidalis. Pesquisa Veteriária Brasileira 38(7):1259-1263. National Institute of Agricultural Research, La Estanzuela, Casilla de correo 68033, Colonia, Uruguay. E-mail: frcorrea@inia.org.uy

This study aimed to characterize the embryotoxic, teratogenic and abortifacient effect of Poincianella pyramidalis in goats. Twenty pregnant goats with 18 days of gestation were divided into five groups of four animals each. After collection, the leaves of P. pyramidalis were dried in the shade and crushed. The daily feed provided to the goats was equivalent to $3 \%$ of their body weight, being 1\% concentrated feed and 2\% roughage. In Group 1 (control), the provided roughage was Cynodon dactylon (Tifton) hay; in Groups 2, 3 and 4, 10\%, 20\% and $80 \%$ of the $C$. dactylon roughage was replaced by dry and ground P. pyramidalis, respectively. In Group 5, all the roughage was replaced by green P. pyramidalis ad libitum, collected daily. Ultrasonographic examination was performed twice a week throughout the pregnancy. Goats in Groups 1, 2 and 3, delivered normal kids. Two goats in Group 4 aborted at 127 and 90 days of gestation. In group 5, three goats showed embryonic death at 25, 30 and 31 days of gestation and the other goat aborted at 39 days of pregnancy. Malformations were not observed. It is suggested that $P$. pyramidalis, which is very common in the semiarid region of northeastern Brazil, should be considered as an important cause of reproductive losses in this area. Due to its high palatability, it is important to avoid the ingestion of $P$. pyramidalis by pregnant and mating goats.
\end{abstract}

INDEX TERMS: Poisonous plants, embryonic mortality, abortion, goats, Poincianella pyramidalis, plant poisoning, ruminants, toxicoses.

RESUMO.- [Mortalidade embrionária e aborto em caprinos causados pela ingestão de Poincianella pyramidalis.] O objetivo deste trabalho foi estudar o potencial embriotóxico, abortivo e teratogênico da Poincianella pyramidalis em caprinos. Para tanto foram utilizadas 20 cabras prenhes com 18 dias de gestação, divididas em cinco grupos de quatro animais. Depois da coleta, as folhas de P. pyramidalis era secas a sombra e trituradas. A alimentação diária fornecida aos caprinos foi proporcional a $3 \%$ do seu peso vivo, sendo

\footnotetext{
${ }^{1}$ Received on July 4, 2017.

Accepted for publication on July 5, 2017.

${ }^{2}$ Centro de Ciências Agrárias (CCA), Universidade Federal de Paraíba (UFPB), Areia, PB 58397-000, Brazil.

${ }^{3}$ Instituto Nacional de Investigación Agropecuaria (INIA), La Estanzuela, Casilla de Correo 68033, Colonia, Uruguay. ${ }^{*}$ Corresponding author: frcorrea@inia.org.uy
}

$1 \%$ de alimento concentrado e $2 \%$ de volumoso. No Grupo 1 (controle), o volumoso fornecido foi apenas feno de Cynodon dactylon (Tifton). Já nos Grupos 2, 3 e 4, 10\%, 20\% e 80\% do volumoso foi substituído por folhas secas e trituradas de P. pyramidalis, respectivamente. No Grupo 5, todo o volumoso foi constituído por P. pyramidalis verde ad libitum, coletadas diariamente. Para o acompanhamento das gestações, exames ultrassonográficos foram realizados duas vezes por semana, durante toda a gestação. As cabras dos Grupos 1, 2 e 3 pariram cabritos normais. Duas cabras no Grupo 4 abortaram, sendo uma com 127 dias de gestação e outra com 90 dias. No grupo 5 , três cabras apresentaram morte embrionária no 25 ㅇ, $30^{\circ}$ e $31^{\circ}$ dia de gestação e uma cabra abortou no $39^{\circ}$ dia de gestação. No presente estudo não foi observada nenhuma malformação. Com esses resultados e considerando a ampla difusão de P. pyramidalis na região semiárida do nordeste Brasileiro sugere-se que esta planta é uma importante 
causa de perdas reprodutivas na região. Devido a sua alta palatabilidade, recomenda-se evitar a permanência de cabras prenhes em áreas onde ocorre P. pyramidalis.

TERMOS PARA INDEXAÇÃO: Plantas tóxicas, mortalidade embrionária, aborto, caprinos, Poincianella pyramidalis, intoxicação por plantas, ruminantes, toxicoses.

\section{INTRODUCTION}

Poincianella pyramidalis (Tul.) L.P. Queiroz (syn. Caesalpinia pyramidalis Tul.) (Fig.1) belongs to the LeguminosaeCaesalpinioidea family. It is an endemic species in the Caatinga bioma with one of the highest occurrences in the semiarid region of Northeastern Brazil, except for the states of Rio Grande do Norte and Maranhão; it has been registered also in the state of Amazonas (Lewis 1998, Queiroz 2009). P. pyramidalis demonstrates multiple utilities, including timber uses for reforestation, and medical uses. It is also used as roughage for cattle, goats and sheep during the dry season (Maia 2004). Its ethanolic extract has demonstrated analgesic (Santana et al. 2012, Santos et al. 2013), anti-inflammatory (Santana et al. 2012), antibiotic (Lima et al. 2006), antifungal (Cruz et al. 2007), antioxidative (Silva et al. 2011) and gastroprotective (Ribeiro et al. 2013) effects in laboratory animals.

Between 2011 and 2013, during a prolonged drought in the Brazilian semiarid, several farmers registered episodes of abortion and malformation in herds of sheep and goats in areas where $P$. pyramidalis was the main plant. Those areas had small amounts of Mimosa tenuiflora, which causes malformations, embryonic death, and abortion (Pimentel et al. 2007, Dantas et al. 2012, Santos et al. 2012), or Aspidosperma pyrifolium, which causes embryonic death and abortion (Medeiros et al. 2004).

In October 2013, on a visit to a farm in Belém do São Francisco municipality, located in the semiarid region of the state of Pernambuco, Brazil, after a shortage of forage in the pastures, a flock of 350 sheep and 6 rams were transferred to an area of native vegetation (caatinga) with large amounts of $P$. pyramidalis. After 70 days in the pasture,

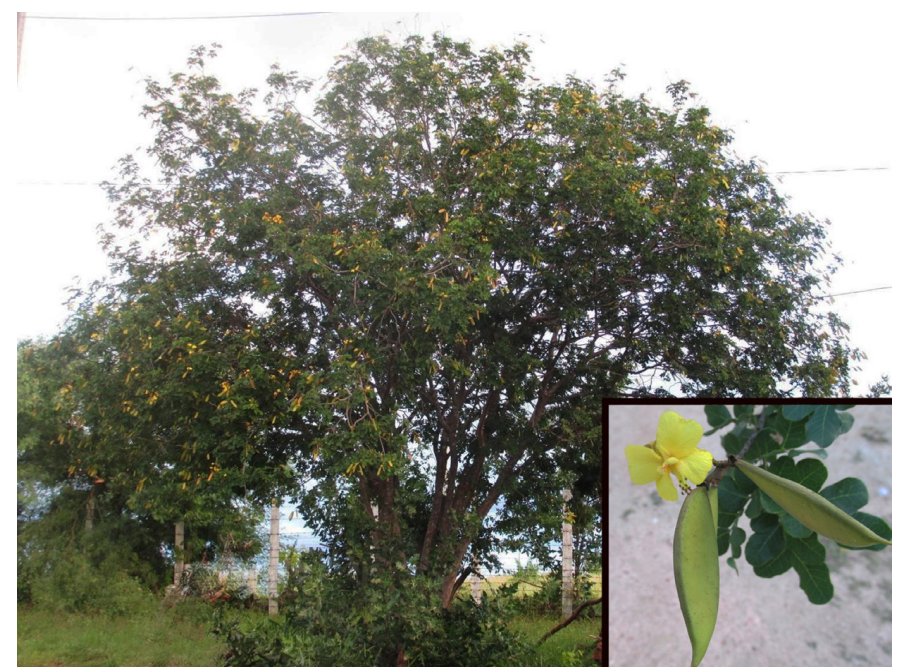

Fig.1. A tree of Poincianella pyramidalis. Inset: flower and pods of the plant. the owner reported the occurrence of estrus returns and vaginal bleeding in some of the sheep. Upon a second visit, in December of the same year, only 20 sheep had lambing, and seven lambs were born malformed, with mandible hypoplasia and limb deformities.

The teratogenic effect of $P$. pyramidalis was recently demonstrated (Reis et al. 2016) in goats ingesting fresh plants that were recently harvested. However, in the semiarid region, the green leaves of this plant have reduced consumption due to their high tannin content, while the dry leaves are readily consumed during the dry season after falling from the trees (Araujo Filho \& Carvalho, 1998). Knowing the toxicity of the dry plant is also necessary for further research on its toxic compound. This study investigated the embryotoxic, abortifacient and teratogenic potentials of dried P. pyramidalis in goats in the semiarid Brazilian region.

\section{MATERIALS AND METHODS}

The ethics committee on animal experimentation of the Federal University of Campina Grande (UFCG) approved this experiment (protocol 69-2013). This study was funded by the National Institute of Science and Technology (INCT), for the Control of Plant Poisonings, CNPq grant 573534/2008-0

The experiment was conducted with 20 goats at the Veterinary Hospital of the Federal University of Campina Grande. The animals underwent ultrasonographic examination for negative pregnancy diagnosis. Later, they were placed with a buck for mating. The buck was marked with red paint on the chest and the date that the goats were found marked was recorded as the first day of pregnancy. Eighteen days after, an ultrasound examination was performed to confirm pregnancy. Pregnant goats were then housed in individual pens and randomly distributed among five experimental groups of four animals each.

The daily feed provided to animals was equivalent to $3 \%$ of their body weight (BW), comprised of $1 \%$ concentrated feed (Guabi Nutrição Animal) and 2\% roughage. In Group 1 (control), the roughage provided was Cynodon dactylon (Tifton) hay; in Groups 2, 3 and 4, $10 \%, 20 \%$ and $80 \%$ of the $C$. dactylon roughage was replaced by dry and ground P. pyramidalis, respectively. Group 5 also ingested concentrated food (1\% BW), but the roughage consisted of leaves, flowers, fresh pods and seeds of Poincianella pyramidalis, ad libitum, collected and provided daily. The leaves of $P$. pyramidalis given to Groups 2, 3 and 4 were collected in the city of São José do Bonfim, state of Paraíba, Brazil. After collection, they were dried in the shade and then crushed and placed in plastic buckets. Every day the dried plant was weighed, mixed with concentrate and provided in the feeder.

In all groups, ultrasound examination was performed twice a week, and the animals were observed daily to detect fetal mortality or abortions.

Serum samples were collected from the goats that aborted for the detection of antibodies to Toxoplasma gondii. Indirect immunofluorescence tests (IFT) were performed using the 1:64 dilution as a cutoff point (Camargo 1974), being tested in paired samples with an interval of 15 days between samplings. Inoculation of mice (Dubey 1998) was also performed using samples of brain and lung from the fetus and placenta from the goats. Autopsies were performed in aborted fetuses and samples of brain, placenta, lung and heart were collected, fixed in $10 \%$ buffered formalin, processed for histological examination and stained with hematoxylin-eosin (HE). 


\section{RESULTS}

In Groups 1 (control), 2 (10\% of Poincianella pyramidalis in dry roughage) and 3 ( $20 \%$ of $P$. pyramidalis in dry roughage), all animals kidded normally. In group 4 (80\% dry P. pyramidalis in roughage), one goat aborted one fetus (Fig.2D) at 127 days of gestation after the ingestion of the plant for 109 days. Another goat aborted two fetuses (Fig.2C) at 90 days of gestation after ingestion of the plant for 72 days. In group 5 (green P. pyramidalis ad libitum), three goats had embryonic mortality at 25 (Fig.2A), 30 (Fig.2B), and 31 days of pregnancy and one aborted on the 39th day of gestation. These animals ingested green plants, respectively, for 7, 12, 13 and 21 days. The IFT for T. gondii was negative in all samples collected from goats that aborted. Toxoplasma gondii was not isolated in any of the inoculated mice. Histopathological lesions were not observed in the aborted fetuses and placentas.

\section{DISCUSSION}

The results of this study demonstrated that Poincianella pyramidalis affects reproduction in goats, causing embryonic losses and abortions. In goats, late embryonic mortality with changes in the estrous cycle occur between the implantation phase and the end of organogenesis, on day 35 of gestation (Gardner et al. 1998). After this day, in the fetal stage, losses were defined as an abortion. The dried plant induced abortions at late stages of pregnancy in Group 3 and the green plant induced late embryonic mortality during organogenesis and early abortion in Group 5. This difference may be due to a higher intake of the green plant $(100 \%$ of the roughage ad libitum) than the dry plant ( $80 \%$ of roughage) or to a partial loss of toxicity during the drying process. However, it is clear that the dry plant was still toxic, and its consumption by the goats during the dry season would cause reproductive losses.

In this trial, it was not possible to demonstrate that P. pyramidalis causes malformations as observed in spontaneous outbreaks associated with the ingestion of the plant (unpublished) and in the experimental poisoning (Reis et al. 2016). Additionally, in rats, P. pyramidalis cause fetotoxicity, postimplantation losses, placental lesions, and a higher frequency of skeletal anomalies (Camara et al. 2017). Some teratogenic plants, like Astragallus spp. and Oxytropis spp., which contain piperidine alkaloids, may cause embryo or fetal mortality by the ingestion of the toxic compound at high doses during pregnancy (Keeler 1984, Panter et al. 1994, Welch et al. 2011). In the semiarid region,

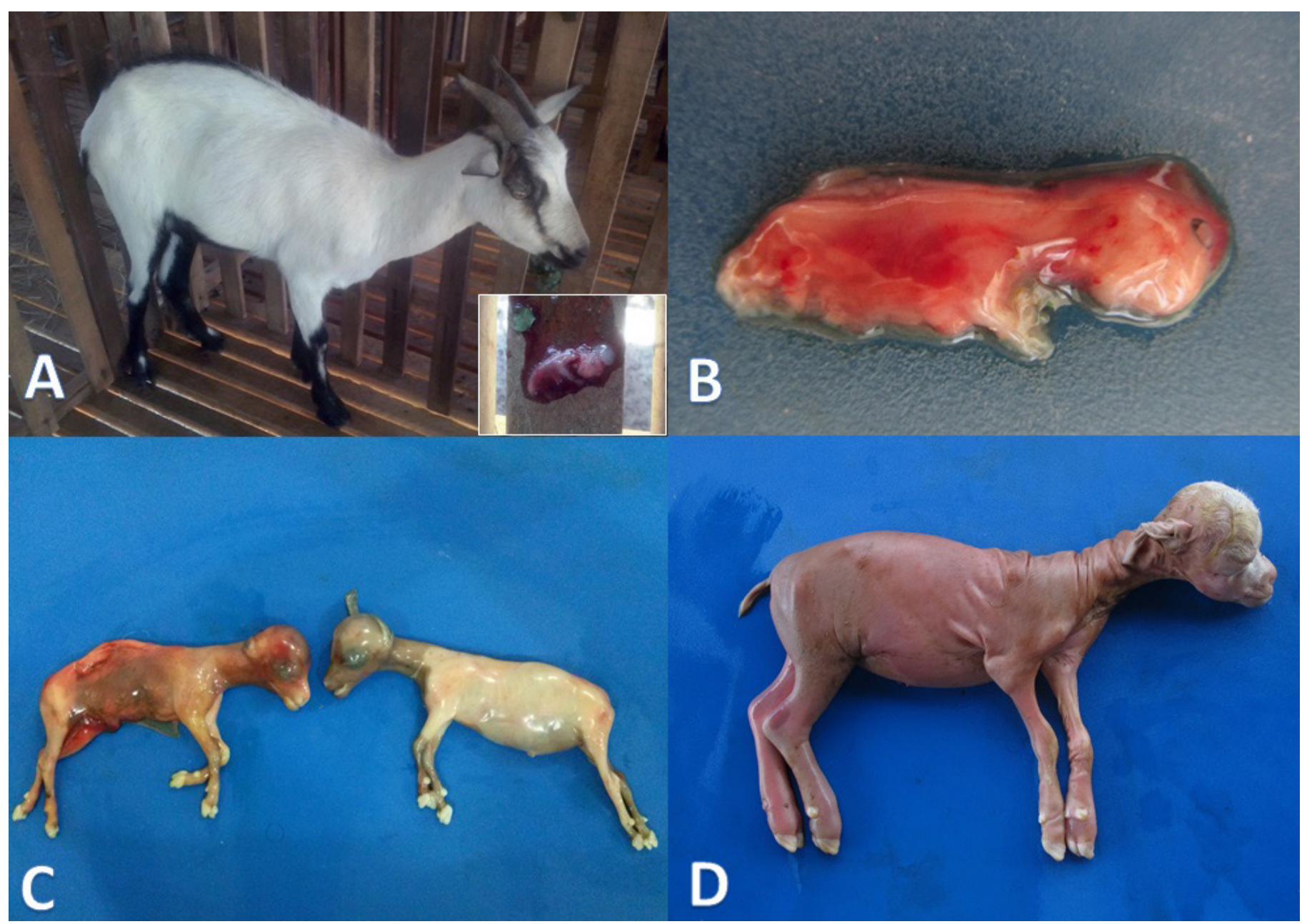

Fig.2. (A) A Moxotó female goat (Group 5) with embryonic mortality after the consumption of fresh Poincianella pyramidalis ad libitum. Its 30-day embryo was found on the floor of the pen (Inset). (B) Embryo of the goat in Figure 2A. (C) Twin fetuses aborted after 90 days by a goat of Group 4 (80\% of dry P. pyramidalis in the roughage). (D) Fetus after 127 days aborted after 127 days by a goat of Group 4 . 
Mimosa tenuiflora is largely associated with malformations (Pimentel et al. 2007, Dantas et al. 2010, Santos et al. 2012) and abortion (Santos et al. 2012) and causes embryonic losses in goats with the absence of malformations (Dantas et al. 2012). Because the malformations reported in $M$. tenuiflora poisoning (Pimentel et al. 2007, Dantas et al. 2010) are very similar to those caused by P. pyramidalis (Reis et al. 2016), and both plants cause embryonic deaths and abortion, it is very probable that they contain a similar toxic compound. The teratogenic compounds in $M$. tenuiflora are suggested to be the tryptamine alkaloids $\mathrm{N}$-methyl and N,N-dimethyltryptamine (Gardner et al. 2014).

Aspidosperma pyrifolium (pereiro) is also a very common plant in the Brazilian semiarid region, which induces embryonic losses, abortions, and perinatal mortality in goats (Medeiros et al. 2004). Although its toxic principle is still unknown, a large number of metabolites have been isolated from $P$. pyramidalis, including phenylpropanoids, lupeol, $\beta$-sitosterol, bioflavonoids (agastiflavone, amentoflavone, sequoiaflavone and podocarpusflavone), chalcone, kaempferol, apigenin, lignane, stigamasterol and methyl gallate (Mendes et al. 2000, Novais et al. 2003, Bahia et al. 2005, 2010). M. tenuiflora and $A$. pyrifolium, along with $P$. pyramidalis, are very common in the caatinga and should be considered in the differential diagnosis of embryonal death and abortions in small ruminants. Malformations are not reported in poisoning by A. pyrifolium (Medeiros et al. 2004).

$P$. pyramidalis is palatable for ruminants and, similar to other xerophilous plants, may sprout at the start of the rainy season; with few rains occurring in these conditions, foraging is nearly the only method available. Additionally, after the end of the rainy season, it continues to have leaves for a long time, while the other plants become dry, and the animals still consume the green leaves in the tree and the dry leaves fallen from the trees. These conditions and its high palatability (Hardesty et al. 1988), mainly of the dry leaves (Araujo Filho \& Carvalho 1998), contribute to their consumption in large amounts by cattle, sheep and goats, with the risk of poisoning in pregnant and mating ruminants.

\section{CONCLUSIONS}

It is concluded that Poincianella pyramidalis is an important cause of embryonic death and abortion in goats in the Brazilian semiarid region and that the leaves of the plant maintain their toxicity after being dried.

Therefore, introducing pregnant goats to areas where the plant is abundant is not recommended.

Acknowledgements.- The authors are grateful to the National Institute of Science and Technology (INCT), for the Control of Plant Poisonings, for funding this research project.

\section{REFERENCES}

Araújo Filho J.A. \& Carvalho F.C. 1998. Fenologia e valor nutritivo de espécies lenhosas caducifólias da caatinga. Comunicado Técnico 39, Embrapa Caprinos, Sobral. $5 p$.

Bahia M.V., David J.P. \& David J.M. 2010. Occurrence of biflavones in leaves of Caesalpinia pyramidalis specimens. Quim. Nova 33(6):1297-1300.<http:// dx.doi.org/10.1590/S0100-40422010000600015>
Bahia M.V., Santos J.B., David J.P. \& David J.M. 2005. Biflavonoids and other phenolics of Caesalpinia pyramidalis (Fabaceae). J. Braz. Chem. Soc. 16(6b):1402-1405. <http://dx.doi.org/10.1590/S0103-50532005000800017>

Camara A.C.L., Gadelha I.C.N., Castro M.B., Medeiros R.M.T., Riet-Correa F. \& Soto-Blanco B. 2017. Embryotoxic effects of Poincianella (Caesalpinia) pyramidalis leaves on pregnant rats. J. Vet. Diagn. Invest. 29(2):137-142. http://dx.doi.org/10.1177/1040638716682564.

Camargo M.E. 1974. Introdução às técnicas de imunofluorescência. Revta Bras. Patol. Clín. 10:143-171.

Cruz M.C., Santos P.O., Barbosa Junior A.M., De Mélo D.L., Alviano C.S., Antoniolli A.R., Alviano D.S. \& Trindade R.C. 2007. Antifungal activity of Brazilian medicinal plants involved in popular treatment of mycoses. J. Ethnopharmacol. 111(2):409-412. <http://dx.doi.org/10.1016/j. jep.2006.12.005><PMid:17234376>

Dantas A.F.M., Riet-Correa F., Medeiros R.M.T., Galiza G.J.N., Pimentel L.A., Anjos B.L. \& Mota R.A. 2010. Malformações congênitas em ruminantes no semiárido do Nordeste Brasileiro. Pesq. Vet. Bras. 30(10):807-815. <http://dx.doi.org/10.1590/S0100-736X2010001000002>

Dantas A.M.F., Riet-Correa F., Medeiros R.M.T., Lopes J.R., Gardner D.R., Panter K. \& Mota R.A. 2012. Embryonic death in goats caused by the ingestion of Mimosa tenuiflora. Toxicon 59(5):555-557. <http://dx.doi.org/10.1016/j. toxicon.2011.11.020><PMid:22178006>

Dubey J.P. 1998. Toxoplasmosis, sarcocystosis, isosporosis, andcyclosporosis, p.579-697. In: Palmer S.R., Soulsbly, E.J.L. \& Simpson D.J.H. (Eds), Zoonosis. Oxford University Press, Oxford.

Gardner D.R., Panter K.E., Stegelmeier B.L., James L.F., Ralphs M.H., Pfister J.A. \& Schoch T.K. 1998. Livestock poisoning by teratogenic and hepatotoxic range plants, p.303-306. In: Garland T. \& Barr A.C. (Eds), Toxic Plants and Other Natural Toxicants. CAB International, New York.

Gardner D., Riet-Correa F., Lemos D., Welch K., Pfister J. \& Panter K. 2014. Teratogenic effects of Mimosa tenuiflora in a rat model and possible role of $N$-methyl- and $N, N$-dimethyltryptamine. J. Agricult. Food Chem. 62(30):7398-7401. http://dx.doi.org/10.1021/jf5005176.

Hardesty L.H., Box T.W. \& Malechek J.C. 1988. Season of cutting affects biomass production by coppicing browse species of the Brazilian caatinga. J. Range Manag. 41(6):447-480.<http://dx.doi.org/10.2307/3899520>

Keeler R.F.1984. Teratogens in plants. J. Anim. Sci. 58(4):1029-1039. <http:// dx.doi.org/10.2527/jas1984.5841029x > <PMid:6373705>

Lewis G.P. 1998. Caesalpinia: a revision of the Poincianella-Erythrostemon group. Royal Botanic Gardens, Kew, Richmond England. 233p.

Lima M.R.F., Luna J.S., Santos A.F., Andrade M.C.C., Sant'Ana A.E.G., Genet J.-P., Marquez B., Neuville L. \& Moreau N. 2006. Anti-bacterial activity of some Brazilian medicinal plants. J. Ethnopharmacol. 105(1/2):137-147.<http:// dx.doi.org/10.1016/j.jep.2005.10.026> <PMid:16356672>

Maia G.N. 2004. Catingueira, p.159-169. In: Maia G.N. (Ed.), Caatinga:árvores e arbustos e suas utilidades. Leitura e Arte, São Paulo.

Medeiros R.M.T., Neto S.A., Riet-Correa F., Schild A.L. \& Sousa N.I. 2004. Mortalidade embrionária e abortos em caprinos causados por Aspidosperma pyrifolium. Pesq. Vet. Bras. 24(Supl. ):42-43.

Mendes C.C., Bahia M.V., David J.M. \& David J.P. 2000. Constituents of Caesalpinia pyramidalis. Fitoterapia 71(2):205-207. <http://dx.doi.org/10.1016/ S0367-326X(99)00145-8> <PMid:10727824>

Novais T.S., Costa J.F.D., David J.P.L., David J.M., Queiroz L.P., França F., Giulietti A.M., Soares M.B.P. \& Santos R.R. 2003. Atividade antibacteriana em alguns extratos de vegetais do semi-árido brasileiro. Revta Bras. Farmacogn. 13(2):5-8. <http://dx.doi.org/10.1590/S0102-695X2003000400003>

Panter K.E., James L.F., Gardner D.R. \& Molyneux R.J. 1994. The effects of poisonous plants on embryonic and fetal development in livestock, p.325332. In: Colegate S.M. \& Dorling P.R. (Eds), Plant Associated Toxins. CAB International, Wallingford, UK. 
Pimentel L.A., Riet-Correa F., Gardner D., Panter K.E., Dantas A.F.M., Medeiros R.M.T., Mota R.A. \& Araujo J.A.S. 2007. Mimosa tenuiflora as a cause of malformations in ruminants in the Northeastern Brazilian semiarid rangelands. Vet. Pathol. 44(6):928-931. <http://dx.doi.org/10.1354/ vp.44-6-928>

Queiroz L.P. 2009. Leguminosas da caatinga. Universidade Estadual de Feira de Santana, Feira de Santana. 467p.

Reis S.D.S., Oliveira R.S., Marcelino S.A.C., Macêdo J.T.S.A., Riet-Correa F., Pimentel L.A. \& Pedroso P.M.O. 2016. Congenital malformations and other reproductive losses in goats due to poisoning by Poincianella pyramidalis (Tul.) L.P. Queiroz (=Caesalpinia pyramidalis Tul.). Toxicon 118:91-94. <http://dx.doi.org/10.1016/j.toxicon.2016.04.043>

Ribeiro A.R.S., Diniz P.B.F., Estevam C.S., Pinheiro M.S., Albuquerque-Junior R.L.C. \& Thomazzi S.M. 2013. Gastroprotective activity of the ethanol extract from the inner bark of Caesalpinia pyramidalis in rats. J. Ethnopharmacol. 147(2):383-388. <http://dx.doi.org/10.1016/j.jep.2013.03.023> $<$ PMid:23506986>

Santana D.G., Santos C.A., Santos A.D., Nogueira P.C., Thomazzi S.M., Estevam C.S., Antoniolli A.R. \& Camargo E.A. 2012. Beneficial effects of the etanol extract of Caesalpinia pyramidalis on the inflammatory response and abdominal hiperalgesia in rats with acute pancreatitis. J. Ethnopharmacol.142(2):445455. <http://dx.doi.org/10.1016/j.jep.2012.05.015><PMid:22626927>

Santos C.A., Santos D.S., Santana D.G. \& Thomazzi S.M. 2013. Evaluation of mechanisms involved in the antinociception of the etanol extract from the rinner bark of Caesalpinia pyramidalis in mice. J. Ethnopharmacol.14(1):205209. <http://dx.doi.org/10.1016/j.jep.2013.03.081><PMid:23603194>

Santos J.R.S., Dantas A.F.M. \& Riet-Correa F. 2012. Malformações, abortos e mortalidade embrionária em ovinos causada pela ingestão de Mimosa tenuiflora (Leguminosae). Pesq. Vet. Bras. 32(11):1103-1106. <http:// dx.doi.org/10.1590/S0100-736X2012001100005>

Silva C.H.T.P., Peixoto Sobrinho T.J.S., Almeida e Castro V.T.N., Lima D.C.A. \& Amorim E.L.C. 2011. Antioxidant capacity and phenolic content of Caesalpinia pyramidalis Tul. and Sapium glandulosum (L.) morang from Northeastern Brazil. Molecules 16(6):4728-4739. <http://dx.doi. org/10.3390/molecules16064728 > <Mid:21654579>

Welch K.D., Lee S.T., Gardner D.R., Panter K.E., Stegelmeier B.L. \& Cook D. 2011 Dose-response evaluation of Veratrum californicum in sheep, p.243-250. In: Riet Correa F., Pfister J., Schild A.L. \& Wierenga T. (Eds), Poisoning by Plants, Mycotoxins and Related Toxins. CAB International, Wallingford, UK. <http://dx.doi.org/10.1079/9781845938338.0243> 